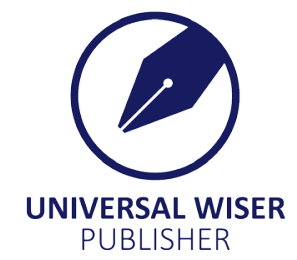

\title{
The Socio-Cultural Context of Akan Ethno-Musical Games and Their Relevance to the Lives of Children in Ashanti Region
}

\author{
Kwaku Owusu Agyeman ${ }^{*}$, John Kofi Brewu ${ }^{2}$ \\ ${ }^{1}$ Saint Monica's College of Education, post office box 250, Mampong-Ashanti, Ghana \\ ${ }^{2}$ Akrokerri College of Education, post office box 32, Akrokerri-Adanse \\ Email: kowusu759@gmail.com
}

\begin{abstract}
Musical-games present a highly pervasive new platform to create, perform, appreciate and transmit knowledge among children. This study therefore sought to identify the enthno-musical games among Akan children in the Ashanti region that could be relevant to their cognitive development. The study mainly used ethnographic research case study design. Observation, video recording and focus group discussion were used to glean data from study participants. The findings were presented in text and notations. The study found the ethno-musical games among the study participants to

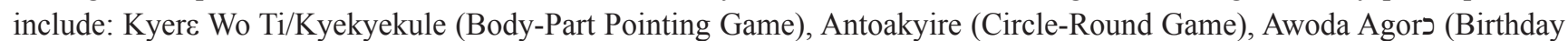

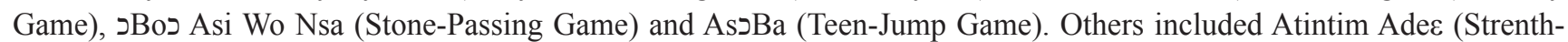
Test Game), Pempenaa (Elimination Game), Dua O Dua (Mammal Tail Game) among several others in the study area. The study found these ethno-musical games to present a unique, yet relatively untapped activities to help cognitive development of children. This warrants investigation of the potentials of these ethno-musical games to promote engagement with music, and the wider benefits of cognitive and psychomotor development in the lives of children.
\end{abstract}

Keywords: ethno-musical games, Antoakyire, Awoda Agoro, Pempenaa and Dua O Dua

\section{Introduction}

Musical games are types of games played with music accompaniment. It has also been defined as types of games where a music thought is both a driving force and carrier of all the activities happening in the game $\mathrm{e}^{[1-2]}$. They are mostly played by children in their homes or within the community and in schools. The song or music dictates the pace, mood, and mode of actions to be performed, be it skipping, jumping, walking, marching, galloping, rolling, running among others. There are so many benefits to listening to music, aside from the fun aspect. Even though fun is a huge motivator to get children engaged, it should not be simply looked at as fun only. Musical games have been found to be profound in ensuring children's brain development and children who are immersed in music and language are more prepared to listen, more receptive and alert, and more active in their responses ${ }^{[3-5]}$.

For this reason, most children's programmes have music and catchy tunes that kids sing along with and learn along the way. The power of musical games is strong in helping children retain information and memorizing patterns. Strong evidence was found to support the claim that learning to read can be enhanced by using songs and movement to teach children to read, especially if the first words that children learn are words they already know as lyrics in a song ${ }^{[6-10]}$. It is imperative to note that when music is paired with movement, children are engaging and focused on the content. When children are engaged and participating, they are more likely to retain the information being presented ${ }^{[11-12]}$. The Mozart Effect focuses on the effects of children listening to music while learning or practicing a skill ${ }^{[10,13-14]}$. This effect discussed how preschoolers' spatial-temporal reasoning can be enhanced simply by just listening to music that was composed by Mozart ${ }^{[15-16]}$.

Adding music and movement to every day learning helps make these connections for students. The use of musical games was noted as significant to language growth in the National Association for the Education Young Children (NAEYC) expectations for pre-schoolers ${ }^{[17-20]}$. Using musical games in the classroom builds vocabulary and self-expression, which are two goals of literacy and can work together to promote growth in both areas. Reading and singing both have very specific structures and sounds that can provide students with the opportunity to enhance memories, attention spans and language skills ${ }^{[5,21-22]}$. Again, it has been found that using song and movement can help enhance literacy skills. Cooper ${ }^{[5]}$

Copyright (C2020 Kwaku Owusu Agyeman, et al.

DOI: https://doi.org/10.37256/ser.122020444

This is an open-access article distributed under a CC BY license

(Creative Commons Attribution 4.0 International License)

https://creativecommons.org/licenses/by/4.0/ 
and Zdravković et al. ${ }^{[16]}$ state that songs and stories have a strong relationship to each other and have the capacity to boost brain development, increase vocabulary, and promote future academic success. The sounds and foundational structures of reading and singing give early childhood students advances in language skills, increasing memory, and promoting emerging literacy ${ }^{[22-23]}$. Songs, stories, and storytelling-especially for young children-are social learning environments, and it is the social interaction that promotes bonding between individuals while supporting and extending learning ${ }^{[5,20,24]}$.

Through exposure to these types of stories, such as nursery rhymes and chants, children begin engage in this musical environment and it can nurture the musical conversations of children. Engaging in this type of activity can help promote language, attention span, and memory skills ${ }^{[25]}$.

Some other studies have also looked at how using music can promote thinking and increase literacy skills. For example Salmon ${ }^{[26-27]}$ posits that music is inherent to children's experiences and is related to sounds heard every day, which facilitate mental imagery. He further asserted that musical intelligence is the first intelligence to develop, and the use of music, soundtracks or soundscapes to learn is attributed to the individual's musical intelligence.

Aside from the literacy skills be enhanced through music and movement, research has found profound connections between music and movement and mathematics. Geist et al. ${ }^{[28]}$ and Fonteles et al. ${ }^{[29]}$ look into the use of music to support emergent mathematics. In their research, they found that math and music have a link to the brain when exposed very early in life. "We know, for instance, that music contains numerous mathematical constructs within its basic structure. Musical elements such as steady beat, rhythm, tempo, volume, melody, and harmony possess inherent mathematical concepts such as spatial awareness, sequencing, counting, patterning, and one-to-one correspondence, ${ }^{,[25,28,30]}$. Therefore, it is conceivable that listening to a steady beat pattern during mathematics teaching activities in the early childhood classroom could promote better attention and increased engagement in young children.

Musical games give children ample opportunities to use the large muscles in vigorous, energetic physical activities $^{[1,31-33]}$. This implies that when children involve themselves in a play, they are able to develop their muscles and there is co-ordination between the psychomotor and cognitive domains. Children learn to be sociable with their fellow mates and try to adopt and adapt to situations and accept other people's views. Children develop the skill of keeping time and being accurate in performing musical games and learn about events and functions of the body ${ }^{[3,6,32]}$.

In spite of the evidences in support of musical games to enhance children's brain development ${ }^{[2,34-35]}$, not much has been written on it, particularly on enthno-musical games in the Akan enclaves in Ghana. This study therefore, focuses on identifying the Akan ethno-musical games and their relevance to the lives of children in Ashanti region.

\section{Materials and methods}

The study mainly used ethnographic research case study design. This research was conducted by using qualitative approach focused on field research method. This approach was chosen because it was relevant to the understanding of ethno-musical games of the participants. Referring to the principle of qualitative research, researchers act as a key instrument. Therefore, the researchers visited the field directly, adjusting to local time and space to obtain data. In addition, the researchers attempt to build rapport with the subject and other informants in order to obtain comprehensive information.

\subsection{Data collection and study population}

In a multi-faceted approach, two main forms of data were collected: observations in the field and video recordings in the field. Data were collected by observing, reflecting, and writing weekly diary comments for eight weeks. As the number of weeks progressed, additional data were collected in the form of videoing the children musical games. Ten females and five males ranging between the ages of seven (7) and ten (10) were chosen to be part of the study. The number of females was deliberately chosen because it was observed that female children particularly took part in those games. For each session, the researchers jotted down observation points across the main sections of each observation. These included introduction, discussions, class singing, group work, class ensemble work, and class reflections. Additionally, in the light of the aim of the study and the knowledge of interest we found focus groups an appropriate method of data collection to augment the observed data.

\subsection{Analytical tools}

The material was analysed with a qualitative content analytical method. The researchers repeatedly read through the transcribed focus group discussions and highlighted various content-related categories by the song notations respectively. The ethno-musical games that emerged were presented separately in quotations and notations; but also in relation to the material as a whole. 


\section{Results and analysis}

The study found females to play most of the musical games than males. However, none of the games was found to be played by males only. This served the opportunity for the children to develop their affective domains. The study found eighteen ethno-musical games in the study area which was Akan dominated enclave. The ethno-musical games included the following:

\subsection{Kyere Wo Ti/Kyekyekule (body-part pointing game)}

This type of ethno-musical game could be performed by boys and girls separately or together during day time preferably in the open. In this game the children stand, form a circle with one of them in the middle as the leader. The children sing and imitate the leader's actions as are contained in the song:

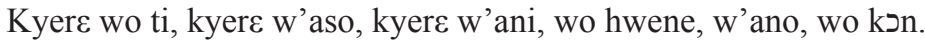

Mew nsa mmienu, afuru kese, ne nan mmienu

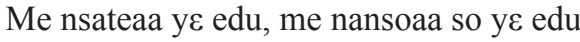

Show your head, show your ear, show your eye, your nose, your mouth, your neck

I have two hands, a big stomach, and two legs.

My fingers are ten, my toes are also ten.

The song Kyekyekule could also be used for this particular game, touching any part of the body as may be directed by the leader (the game deals with parts of the body).

Kyekyekule (response-kyeekule)

Kyekye Kofi Sa

Kofi Salanga

Katakyi Langa

Kum adenne

The music of this game is shown below

KYERE WO TI
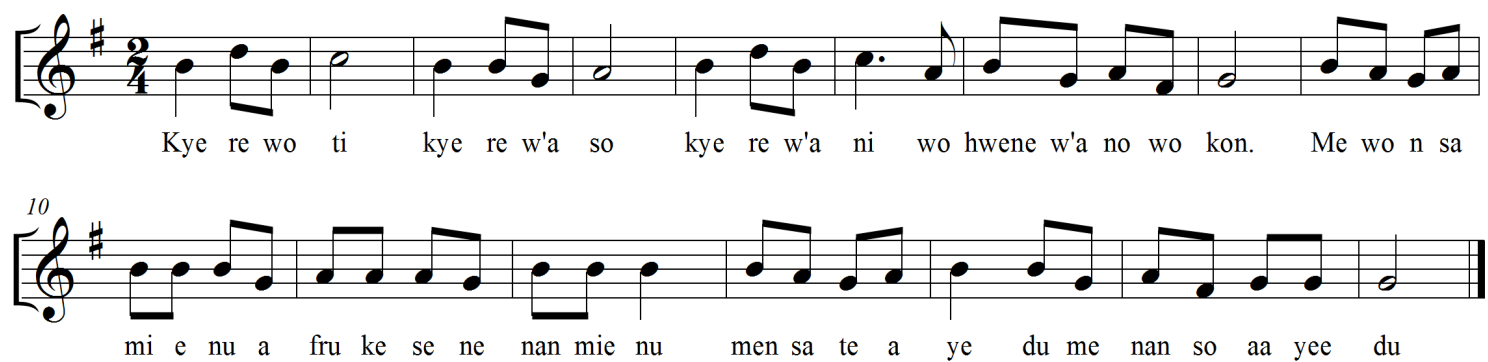

KYEKYEKULE
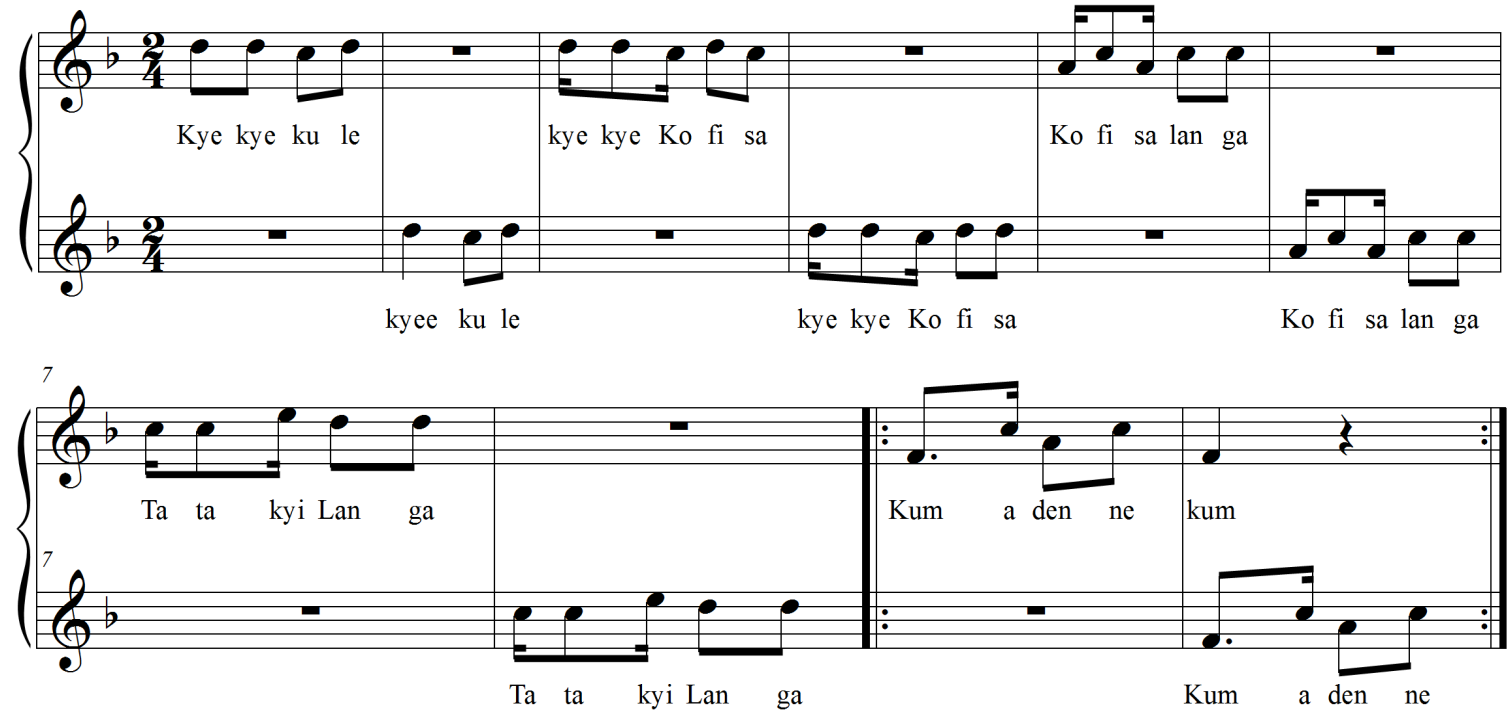

Source: Field Survey, 2019 


\subsection{Antoakyire (circle-round game)}

Performance of this musical game is by both sexes either together or separately. The game cells for an area spacious enough for maximum performance. The most appropriate time for the game is during the day for the purpose of visibility.

The children squat, kneel, or sit in a circular form with one holding an object (be it a rag, stone or handkerchief). As the Antoakyire music goes on, he/she runs round the group and at one point drops the object behind a member. This is done so carefully that the said member in the circle does not recognize that something has been placed behind him/her. No member is to look behind him/her and whoever flouts this rule is dismissed outright.

If the member in the circle is alert and notices that there is an object behind him/her, he/she picks it up and runs after the one who dropped it until the latter gets to the former's place. On the other hand if the object is unnoticed and not taken, the one sitting is "beaten up" and has to be chased until he/she gets to his/her place. He/she then continues the game as the first performer takes his/her (the first) place in the circle.

The game can continue until all participants have had their turns in going round the circle. The words of "Antoakyire" are as follows:

\section{Antoakyire, Tinkon \\ Nhwe w'akyi o Yoo \\ Antoakyire, Tinkon \\ Asaase Mankani Tinkon \\ Woto ma wodi, Tinkon \\ Wənni no kwa. Tinkon}

Antoakyire (It is not behind) Tinkon. Do not look backwards, I have heard Earth's cocoyam.

It is bought before eating. It is not eaten free.
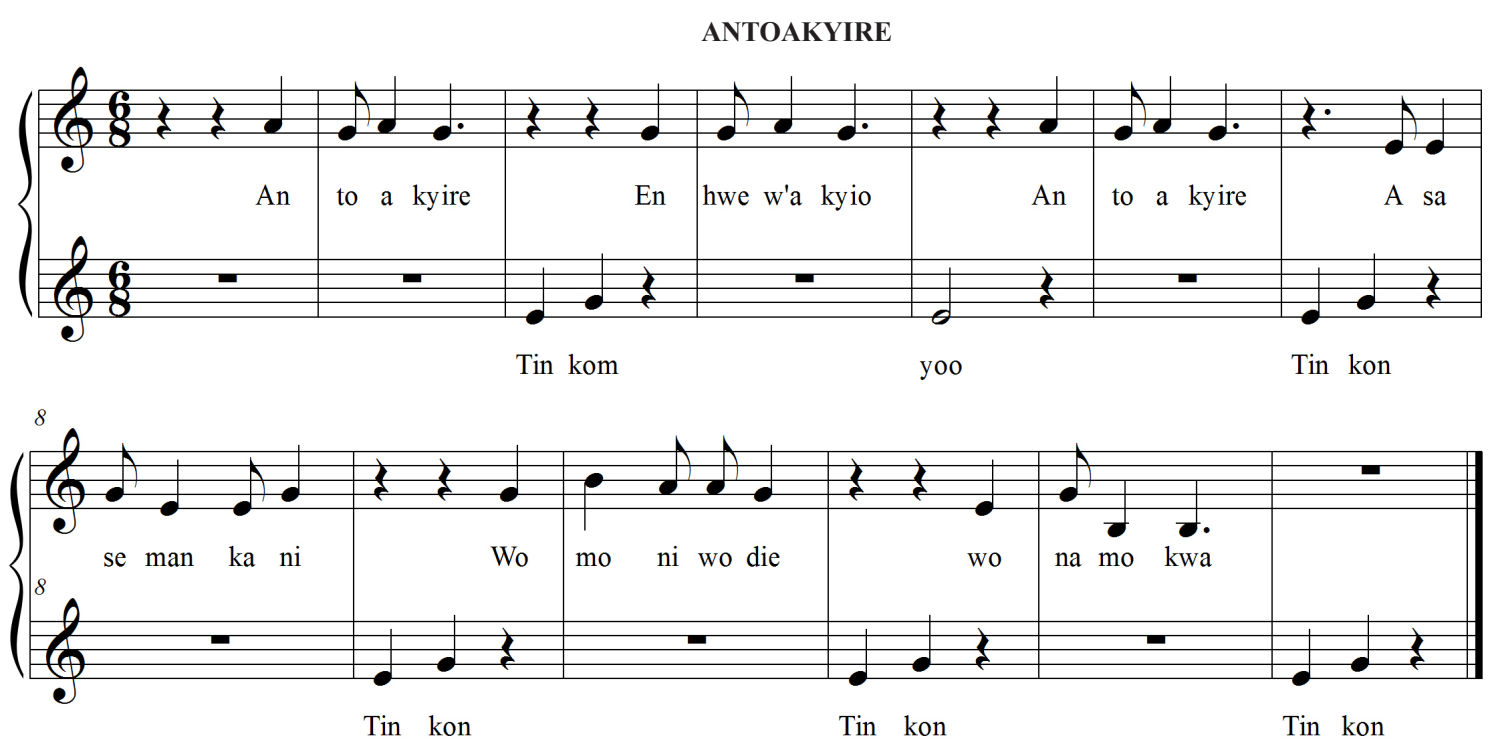

Source: Field Survey, 2019

\subsection{Awoda Agor? (birthday game)}

The Birthday game is intended to involve children born on particular days to do an activity. It is one of the commonest musical games which could be performed by males or females alone or both. Performance is possible during day time or in the evening.

Children form a semi-circle and clap and sing the birthday song inviting particular day-born children to act according to the text of the song. The text may be in this form:

“Obiara w'awo no Dwoada koto, koto:

Tra la la la la la la la

Tra la la la la la la la

Tra la la la"

b) Obiara w'awo no Benada koto, koto.......etc.

All those born on Monday squat. All those born on Tuesday squat 
(After all days are mentioned, another action like "All those born on Monday get up" is introduced for all to get up in turns according to the days mentioned).

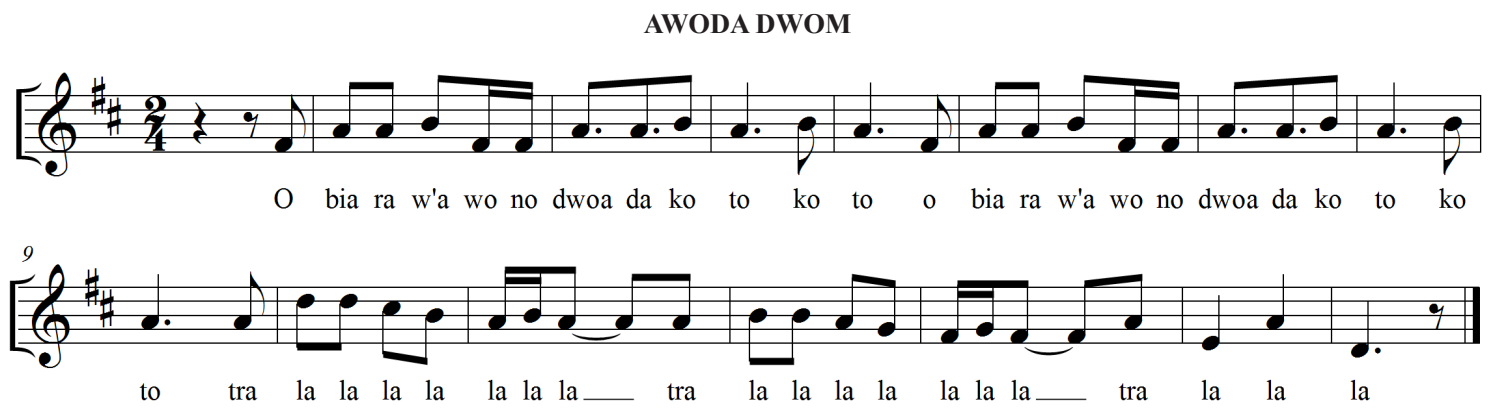

Source: Field Survey, 2019

\subsection{OBos Asi Wo Nsa (stone-passing game)}

This game is best performed by mixed sexes even though it could be acted by a particular gender. The most appropriate time for the game is during the day and on a smooth-level ground surface.

Children squat in circular form with a handy stone in hand and pass on to the next on the right side. As one passes his stone to the next, he also prepares himself to receive others from the left flank.

Any loss of concentration will put one into trouble as there will be a heap of stones from the left side before him. The song that accompanies this game could be any with good and steady rhythmic structure.

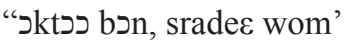

כktכ bכn, srade $\varepsilon$ wom'

Nana Nyame adaworoma

כktככ bכn, srade\& wom'

(JkJtว Bวn, Srade $\varepsilon$ Wom)

OKOTO BON SRADEE WOM
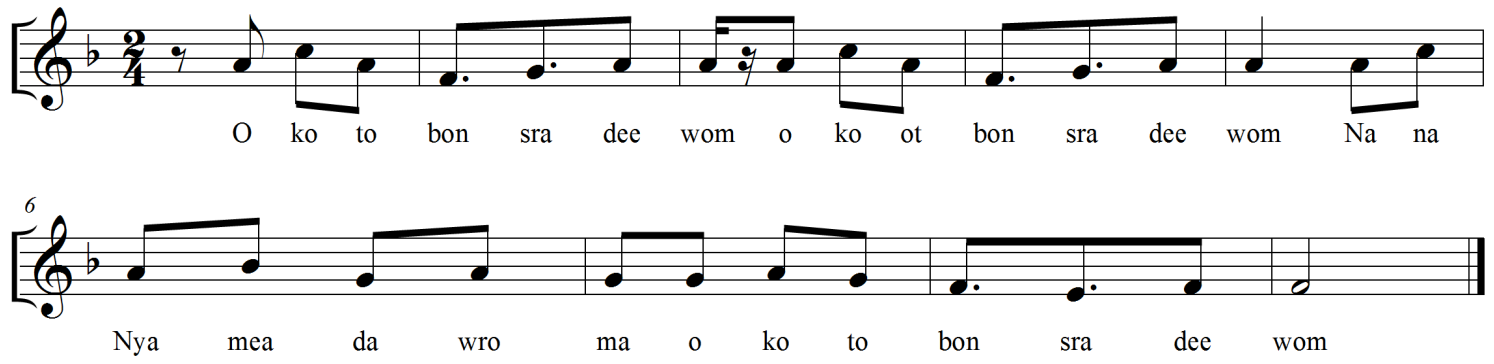

Source: Field Survey, 2019

\subsection{AsəBa or Asə (teen-jump game)}

This is exclusive reserved game for girls which is mainly performed during day time. Girls form a circle with one in the middle. The middle girl throws herself unto those forming the circle at random at random and they are expected to grab her to avoid falling. Other girls take their turns as centre girls. The centre girl is thrown back into the middle after being grabbed by the inmates.

(AS๖BA)

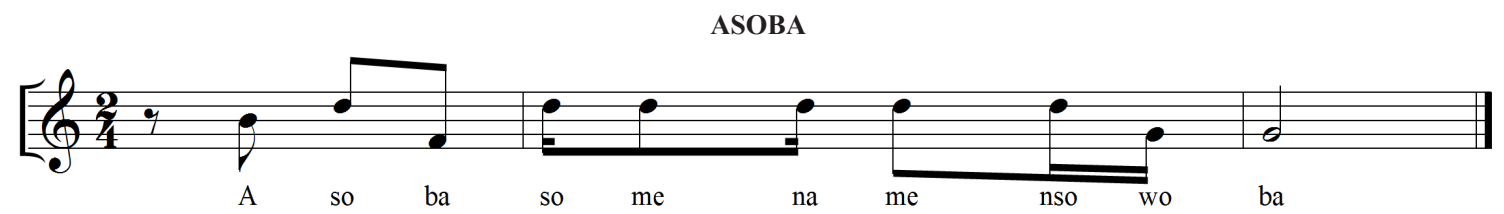

Source: Field Survey, 2019 


\subsection{Merepe Kwan Akכ (path-finding game)}

Boys, girls, or both can perform this musical game, which is normally held in the open. They form a circle with hand joined, having one in the middle. The one in the middle tries to find a way out of the circle by "cutting" through the joining hands of colleagues. There is resistance but if he is able to break the tie, he runs away. He is given a hot chase and whoever touches or catches him takes his turn to search for way.

"Merepe Kwan akכ"

Response: "Wonya"

I am searching for a way-You will not get

(Merepe kwan akə)

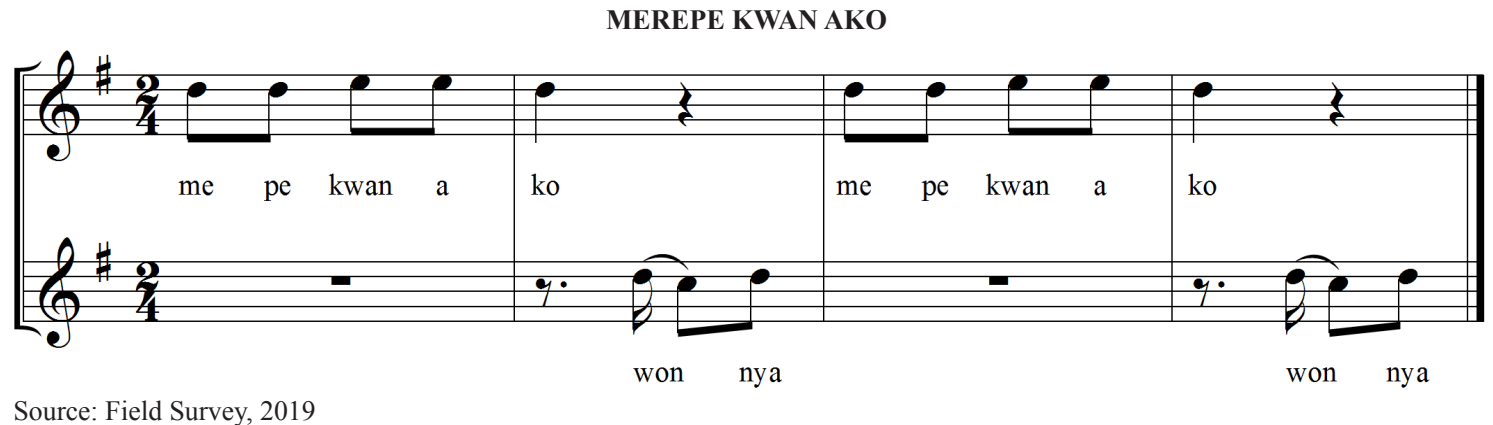

\subsection{Atintim Ade\& (strenth-test game)}

The game is best performed by children of equal sexes. Children form two lines of equal number facing each other clinching fingers. Those in one line pull the others towards them and also reciprocate in the same manner in accordance with the song sung.

Atintim Ade $\varepsilon$

Atintim Atintim

Hold it firmly. Held firmly

(Atintim ade $\varepsilon)$

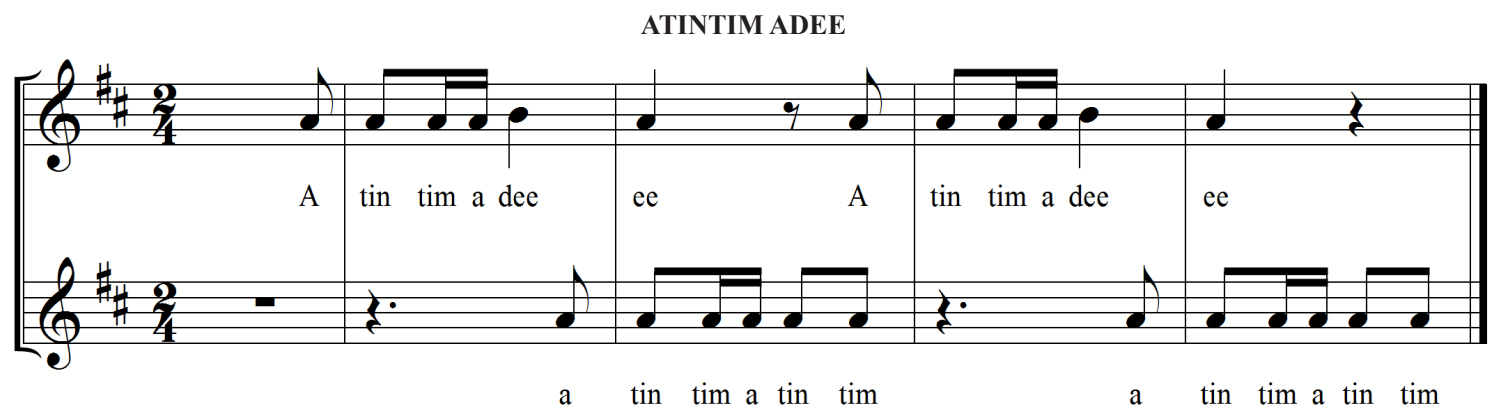

Source: Field Survey, 2019

\subsection{Pempenaa (elimination game)}

Pempenaa played by both sexes. They sit in line with their legs stretched forward. There is a group and a leader. The group sits while the leader stands. The leader begins the game with a song 'pempenaa' the group responds with to the song 'Nanaa'. After that, the leader runs his/her hands on their laps while singing. Whoever the songs ends on his/her lap removes that leg. The one whose both legs come out first takes the first position. It goes on till the last person is declared.

The song is 'pempenaa'.

Pempenaa Nanaa

See see see, see nana koo

Kata b me, bonkoto, bonkoto, bonkoto bonkoto fre me

"Bənkoto call me, father Ananse remove one leg" 

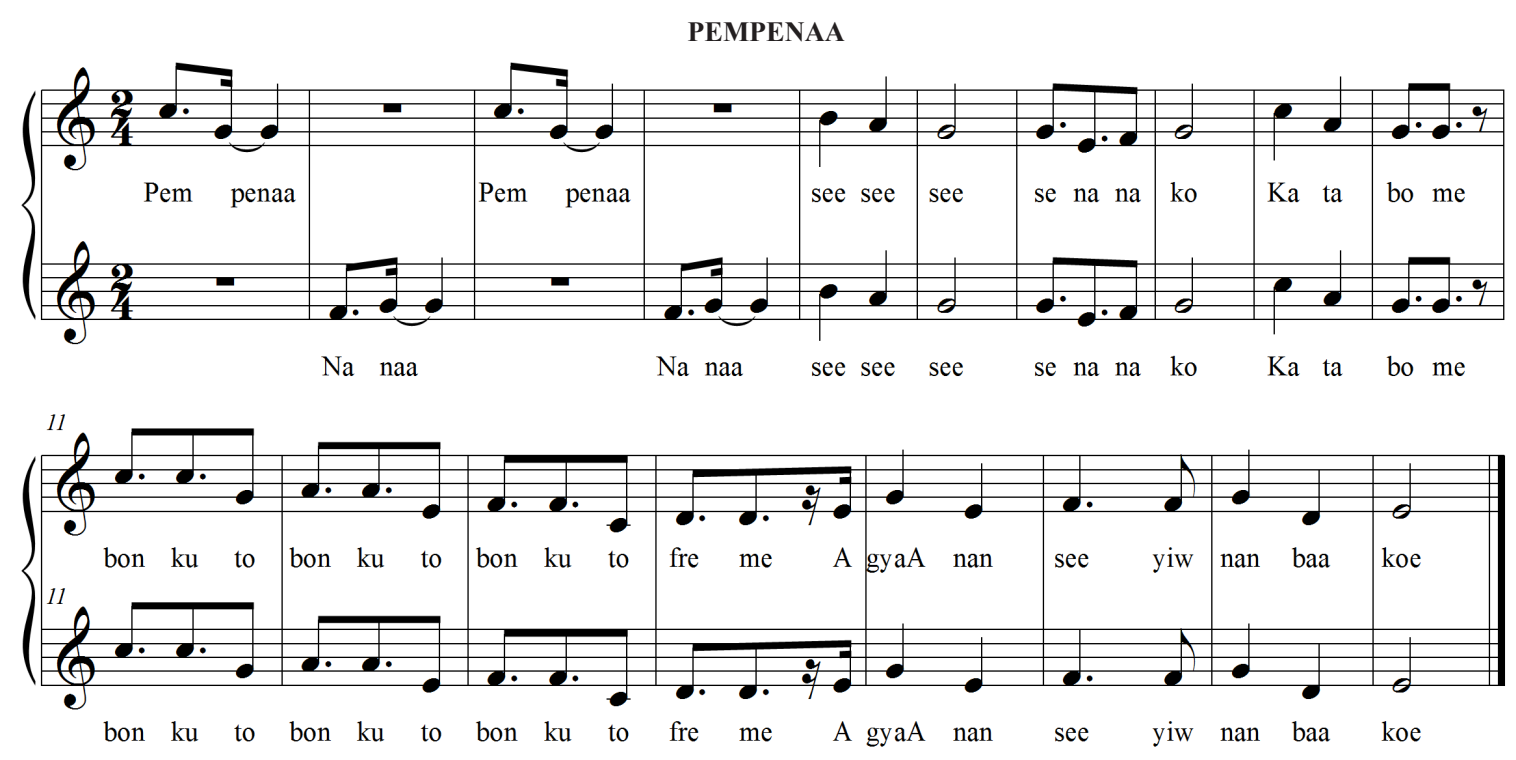

Source: Field Survey, 2019

\subsection{Mo Wə Hen O (where are you game)}

During this game which is enjoyed by both boys and girls, one child is blind-folded and tries to locate his friends by asking "Mo w hen o" (Where are you). They respond "Yen nie o" (Here we are) and he moves towards the direction where the response is coming from. Any unfortunate or careless member who is caught by blind-folded child is made to replace him and to do searching.

(MO W $\supset$ HEN)

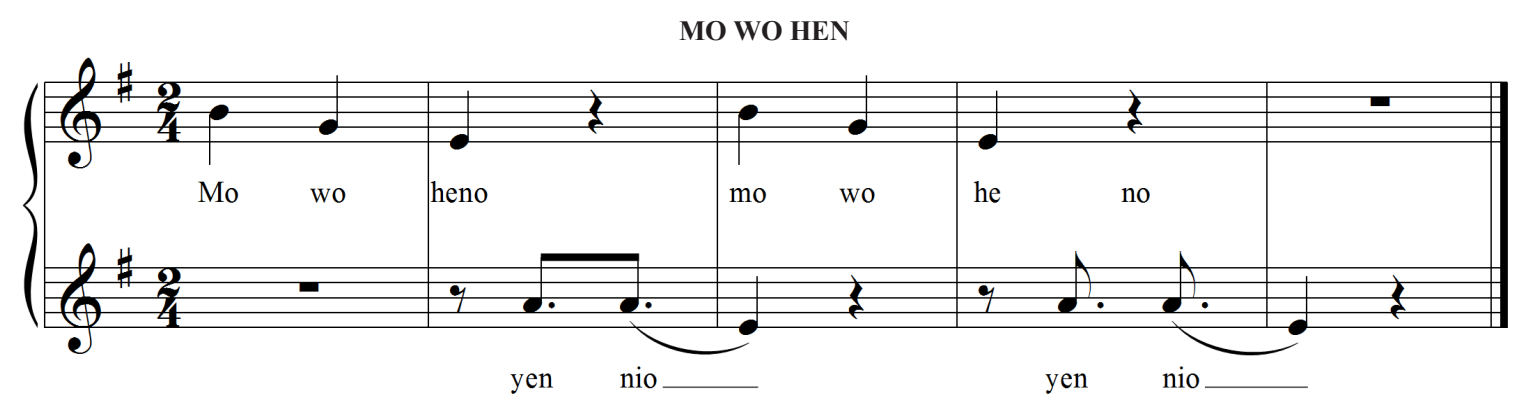

Source: Field Survey, 2019

\subsection{Hwehw\& W'Adamfo (seek your friend game)}

Like most games, children form a circle and one person stands in the middle. As the song is sung he goes round and chooses a friend and does an activity with him as directed by the text in the song. It is also played by both boys and girls

a) "Hwehwe W'adamfo:/:

Hwehwe W'adamfo

Hwehwe W'adamfo

Sesea wo ye no daa'

b) "So no mu na nsa:/: Senea wo ye no daa" etc.

(Search for your friend, as it is done always, hold him and dance etc.) 


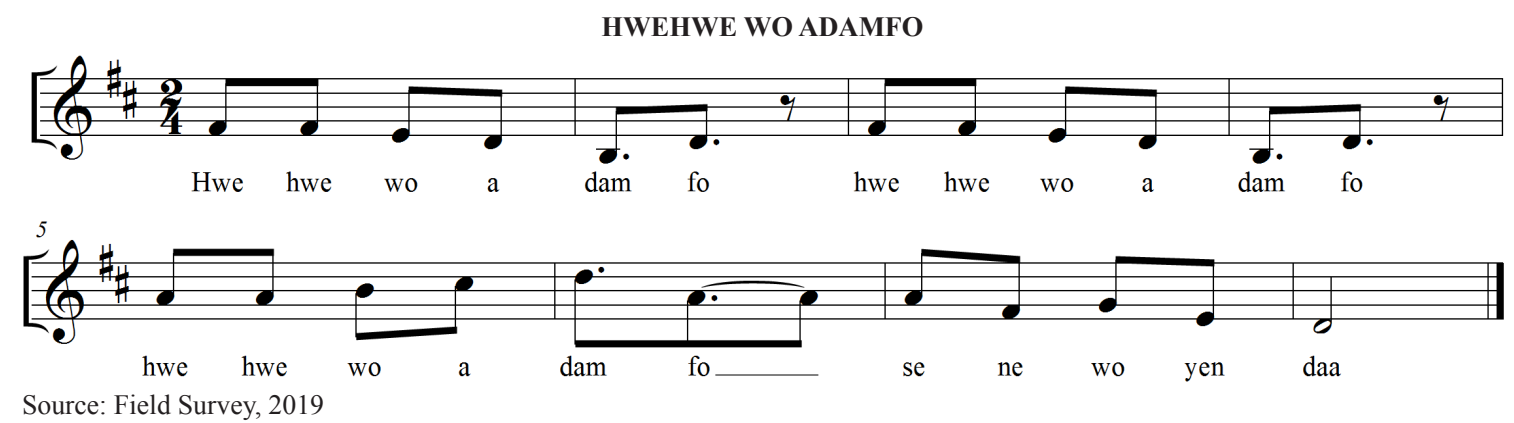

\subsection{Yerekəforo Bepэ (mount-hike game)}

Children form a circle with one of them in the middle and sing. With the song they run round their leader in the centre and increase or reduce the pace as may be directed by the leader. It is performed by both girls and boys

"Mankani no aben,

Momma yenkə di

Na yenkoforo bepə"

(The cocoyam is ready, Let us go and eat, And go to climb the hill)

(Yerekəforo bepכ)

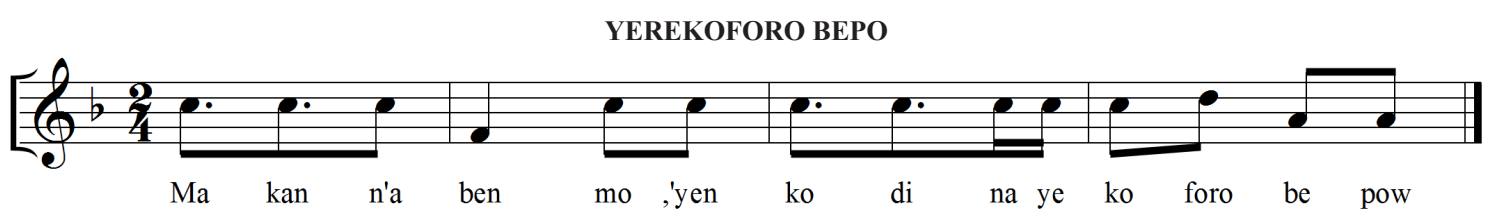

Source: Field Survey, 2019

Another similar game is that "Ogya wכ bepכ so, Tu mmirika" (There is a fire on the mountain, Run)

"Ogya wכ bepכ so

Tu mmirika, tu mmirika

Ogya adum'

At "Ogya adum" children stand still and whoever does not comply is dropped from the game. There is a fire on the mountain, run. The fire is out (quenched)

\subsection{Dua O Dua (mammal tail game)}

This game is performed by boys and girls separately or together preferably during the night when the moonlight is on. During this game a cantor sings a phrase and the others respond. Children could be in any position, be it standing or sitting. The game is about animals that have tails and it is the task of children to echo back what the cantor says if that particular animal has a tail.

Should anyone respond whilst the message is false, he is given few slaps by the colleagues.

The words are:

$\begin{array}{lll}\text { Call } & : & \text { Dua o dua } \\ \text { Response } & : & \text { Dua } \\ \text { Call } & : & \text { Dua Abirekire due } \\ \text { Response } & : & \text { Dua } \\ \text { Call } & : & \text { Dua Nantwi dua } \\ \text { Response } & : & \text { Dua } \\ \text { Call } & : & \text { Dua Jkoto dua } \\ \text { Response } & : & -\end{array}$

(Tail, tail of a Goat, tail of a Rat, tail of a Cow, tail of a Crab: no response because the Crab does not have a tail) 


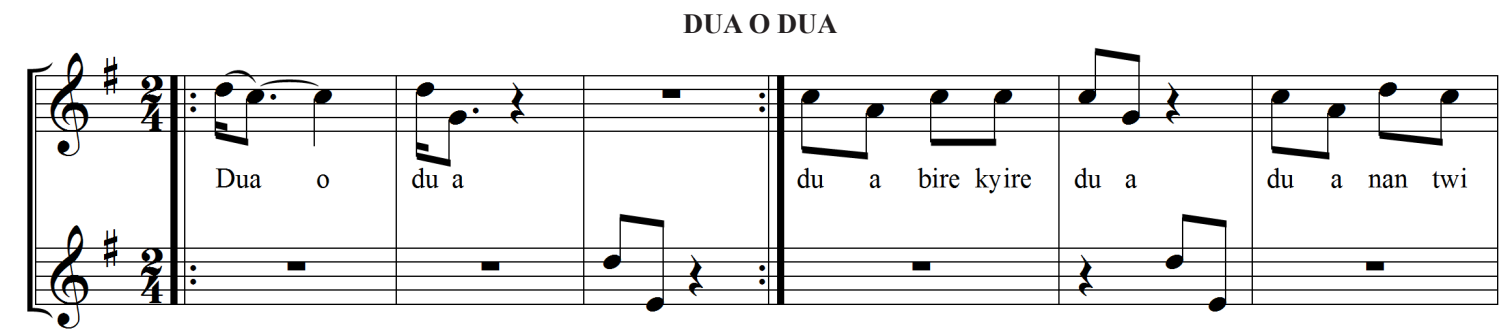

du a

du a

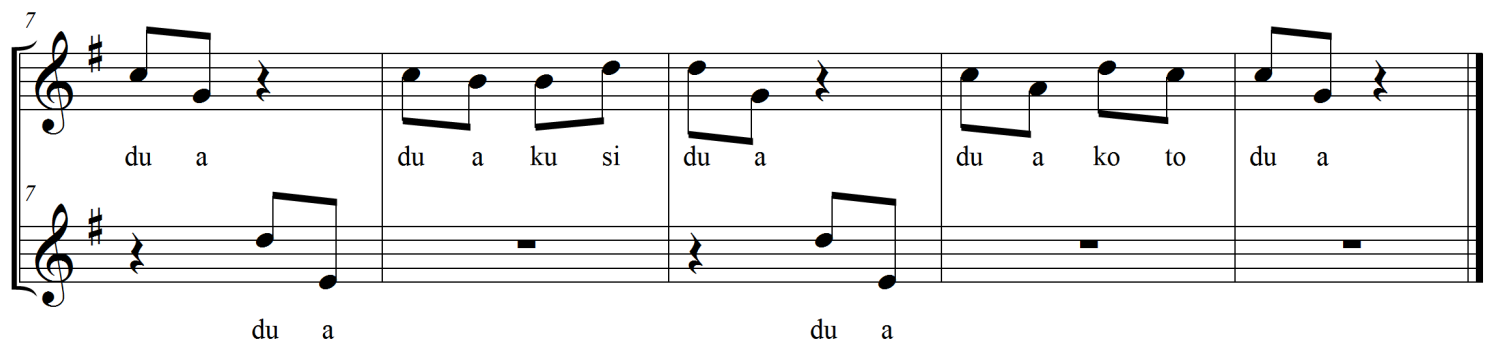

Source: Field Survey, 2019

\subsection{Bankye Bankye (cassava game)}

Bankye bankye is best performed by both boys and girls separately or together. It is mostly performed during the day time and on a smooth level ground. This musical game deals with the various dishes cassava could be converted into. Children form a queue and hold both hands together as if there is a ladle in them ready to steam 'banku'. The move the hands sideways from left to right in tune to the accompanying music:

Bankye Bankye Bankye

Bankye wəde wכ fufuo

Bankye wəde bə ampesie

Bankye wəde ka kokonte

Bankye wつde ye yakayaka

Bankye Bankye

Kokonte-Bankye"

(Cassava is used for fufu, ampesi, konkonte etc.) 
BANKYE BANKYE

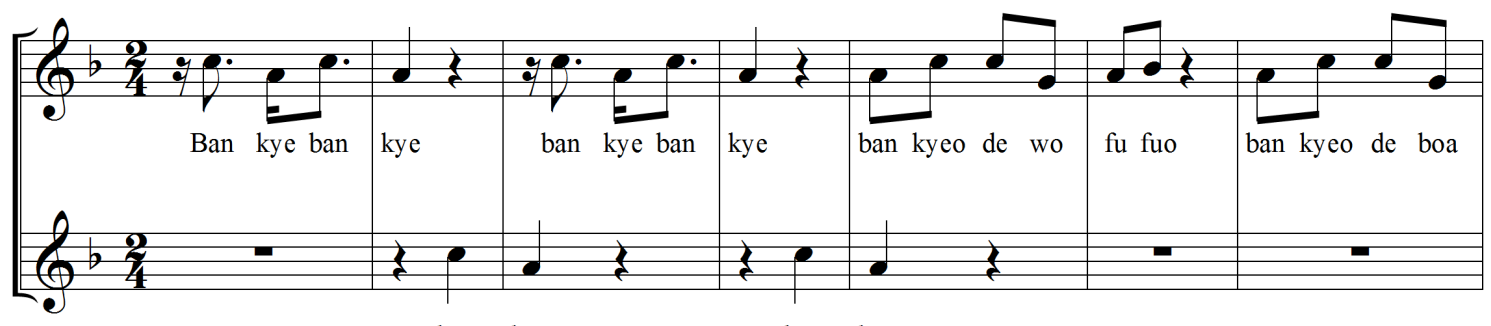

ban kye ban kye
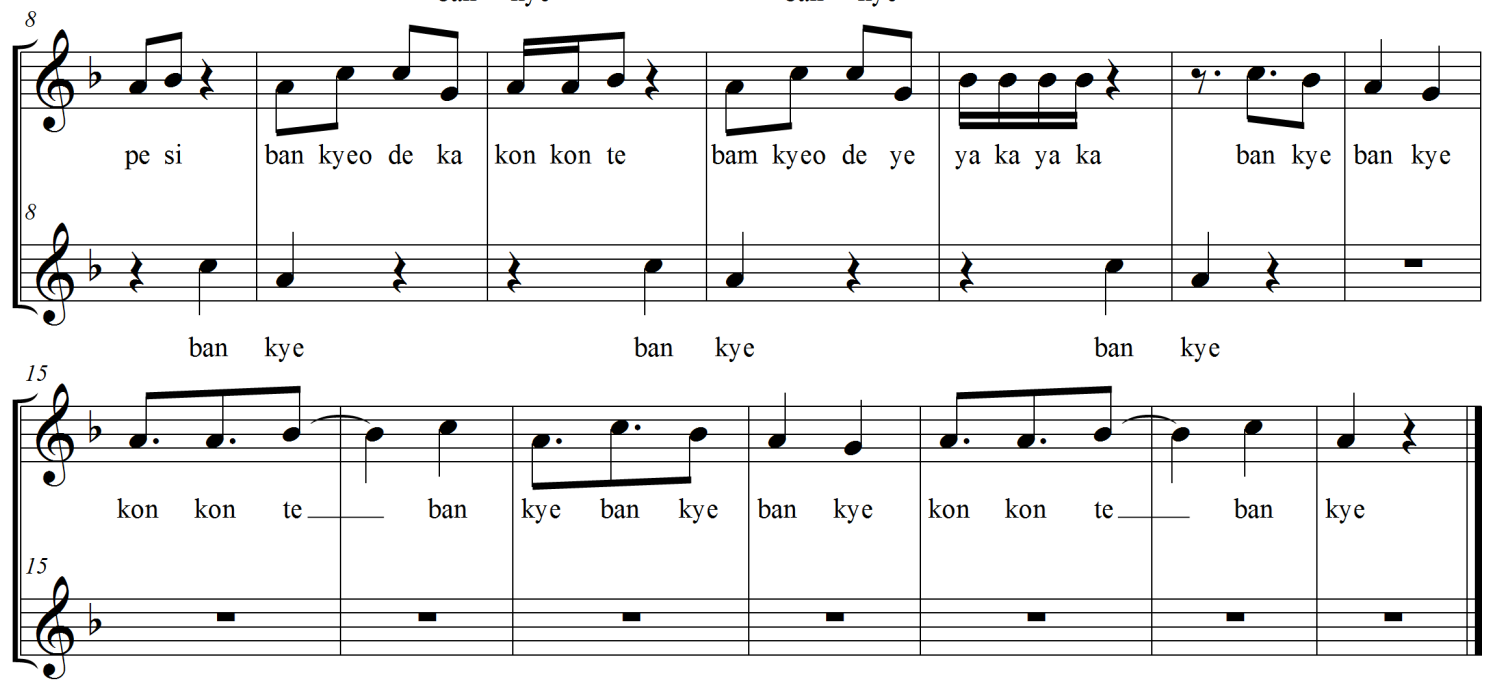

Source: Field Survey, 2019

\subsection{Tuwe-Tuwe (well done game)}

This game is exclusively performed by girls in two lines facing each other. Each child raises the two hands and meets them with the counterpart in other line for two counts and taps the things, repeating the action until the accompanying music is over.

"Tuwe, Tuwe, Maria Tuwe, Tuwe,

Abofra pa w'aye Amaria. Tuwe, Tuwe!

(Well done Maria, a good girl who is properly married, well done!)

TUWE TUWE
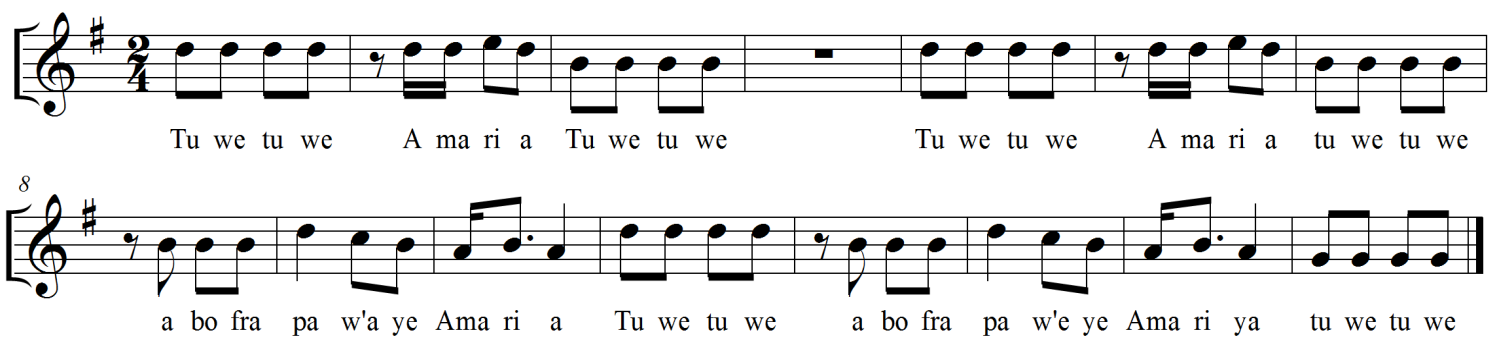

Source: Field Survey, 2019

\subsection{Prapra Gyensamma or Mpeewa (ember game)}

This is also another game for girls in a circle. Each performer raises both arms to shoulder level with the right palm opened upwards and the left downwards opened. The palms keep on alternating (i.e. open upwards, open downwards) as the music accompanying is being sung. Anyone who misses the patterns is dropped and this continues till the last person to survive is declared the winner.

The current well-known song for this game is "Robert Mensah"

"Robert Mensah, Goalkeeper No. 1

Aka nansa na כko Aburokyire, 
כkwasea bi te hכ, כpe ne ho as\&m

כde pentoa aw ne yam

Adec kyee a ne yere wawo

Wawo anto, wanto ne maame,

Kofi Anto, wanto ne papa"

(Robert Mensah, goalkeeper No. 1. He was only left with three days to the abroad, A fool has killed him with a broken bottle. The wife delivers the following day. The child is now an orphan).

PRAPRA GYENSAMMA

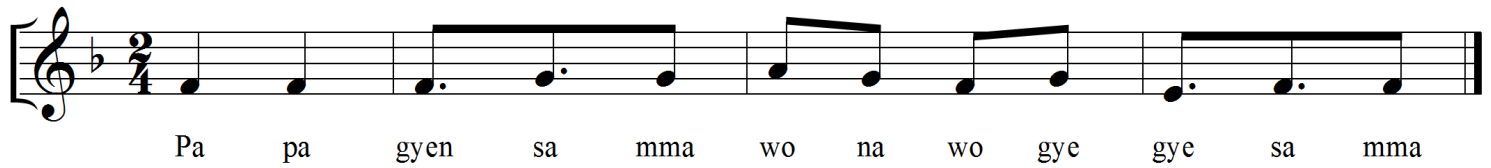

RONERT MENSAH

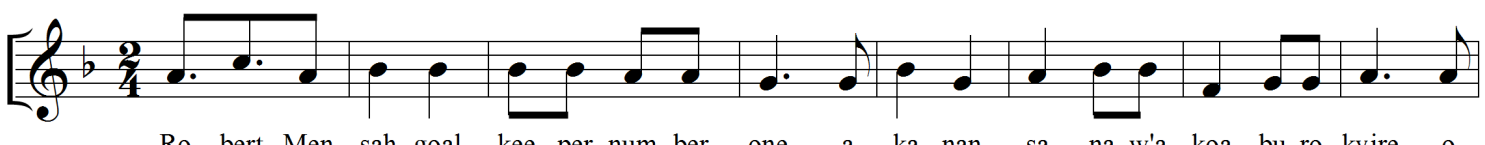

Ro bert Men sah goal kee per num ber one a ka nan sa na w'a koa bu ro kyire o
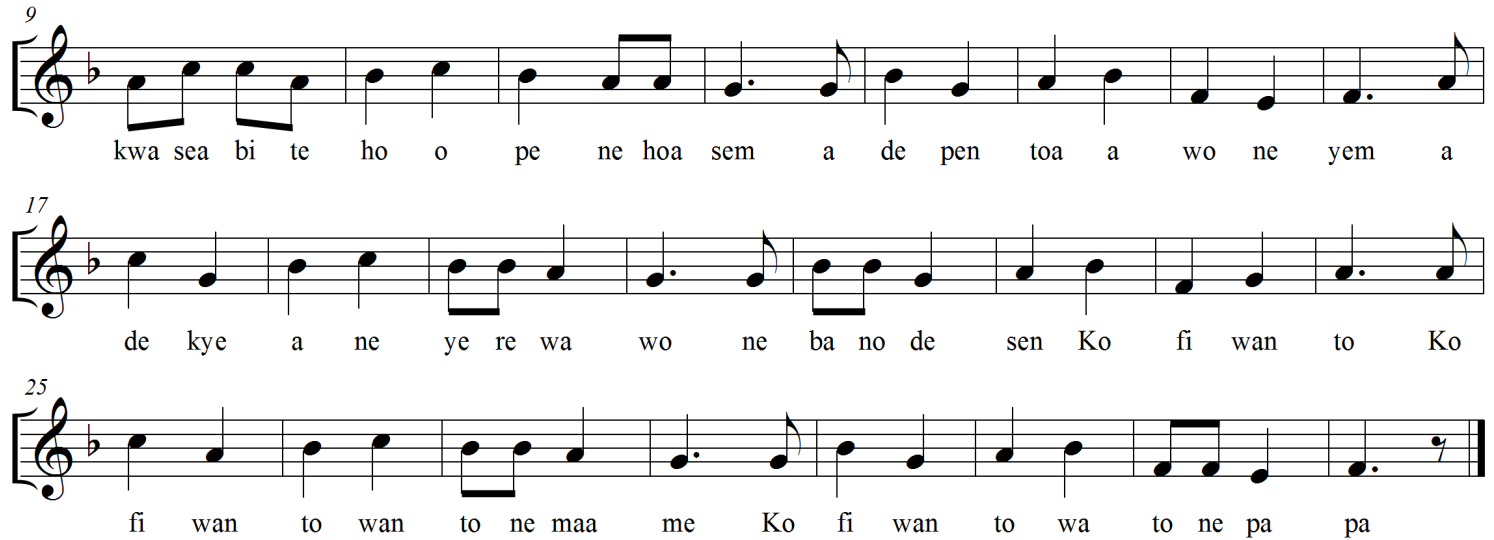

Source: Field Survey, 2019

\subsection{Yi Wo Dofo (friend or lover hunt game)}

Children of mixed sexes form two queues facing one another. As they sing, one child goes to the other group and picks another child of the opposite sex a "over" and the new "couple" dance to the rune of the music in the middle of the two queues. This pattern continues.

"Hwehwe mu na beyi wo dəfo

Bra, bra, bra beyi wo dəfo

(Search through and select your lover, come and pick your lover)

YI WO DOFO

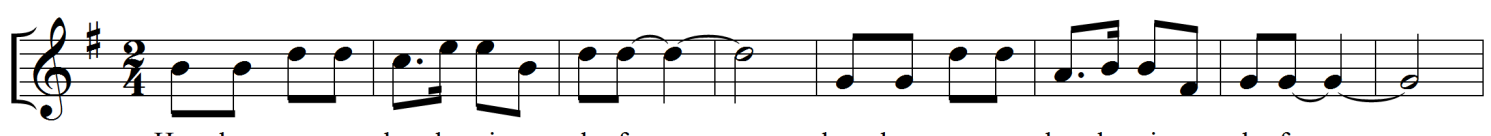

Hwe hwe mu na bra be yi wo do fo_ hwe hwe mu na bra be yi wo do fo

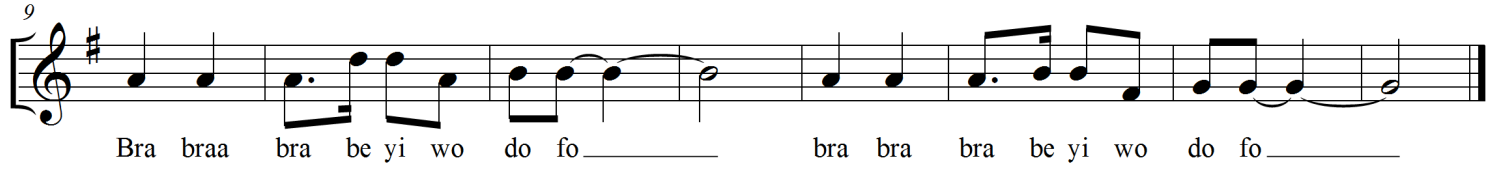

Source: Field Survey, 2019 


\subsection{Piiloloo (treasure hunt game)}

It is a game performed by both sexes even though it can be enjoyed by females and males separately. In this game, a treasure is hidden by one of the participants whilst the other keep off from the place. After some time, the treasurer owner will raise an alarm; others rush to the scene and begin to search for the hidden treasure which is normally pieces of sticks. The sticks are numbered according to the number of pupils involved in the game. Marks are located for the various positions. When one finds one he or she runs to certain place agreed by the whole group and back. Sometimes too just an object is hidden by the leader whilst the group hides somewhere and the 'treasurer owner' raises and alarm and others run to the place to search for. Whoever finds it runs to a given point with it and shouts, 'I have found it'. The finder becomes the treasure owner in the next round.

"Piiloloo

כhys he fa

Piiloloo

Јhyє abe n'ase

Piiloloo", where is it, it is under the palm tree, it is under the basket etc.)

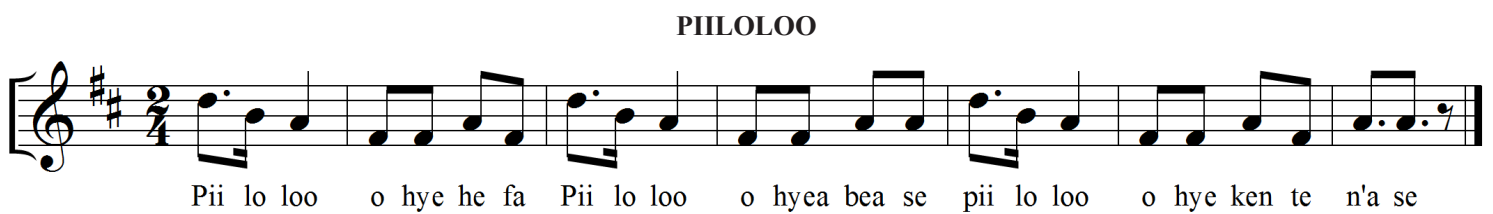

Source: Field Survey, 2019

\subsection{Sansankroma (hawk game)}

Children of both sexes form a circle with one in the centre who acts as a hawk with the others playing the role of chickens. As they sing, they run round the 'hawk' and at a signal, the 'hawk' tries to catch its prey. This disperses the 'chickens' who run to hide at marked points, where their persecutor is not allowed to operate.

"Sansankroma, ne ni awuo,

כkyekye nkokכmma

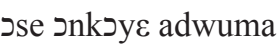

Ne ni awuo

כkyekye nkokəmma"

(The hawk's mother is dead, he catches chickens. He does not want to work)
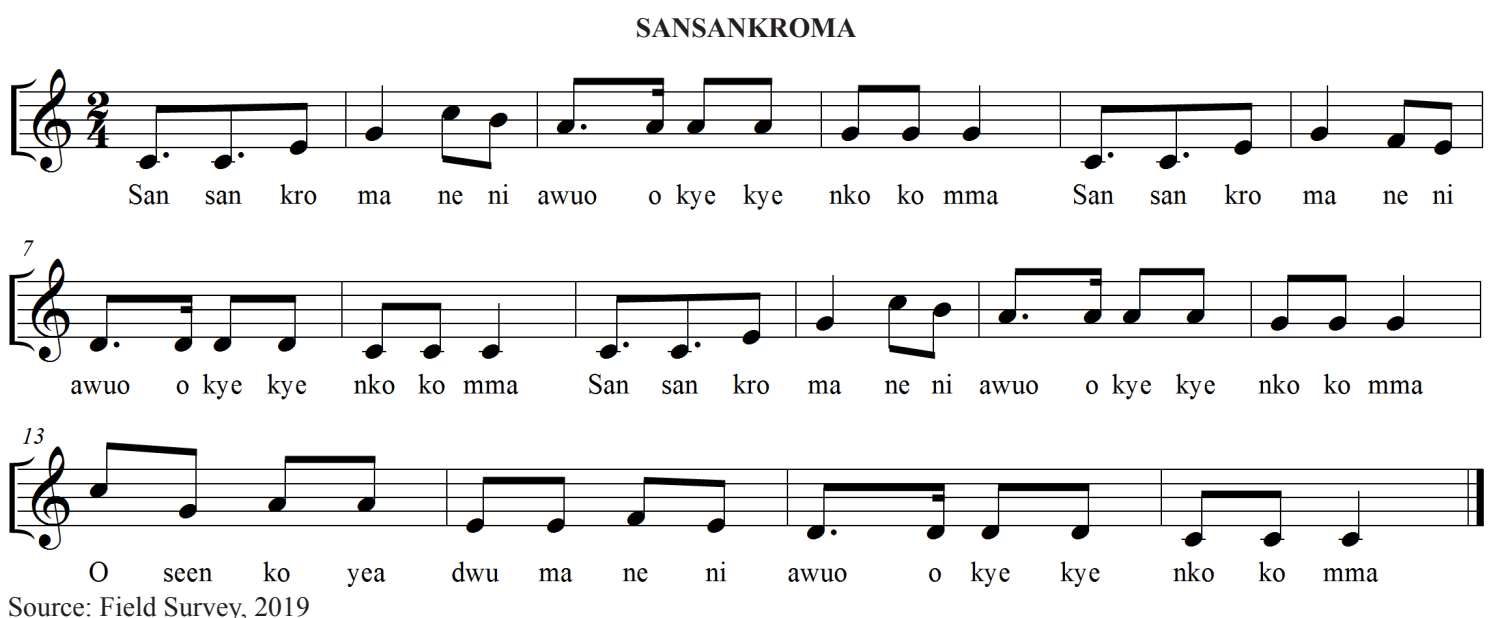

\subsection{Ampe (foot-decider game)}

It is played by females only. It can be played two or more girls with one facing the other. There are two groups in the game, namely 'wכhyia'-where both legs meet 'wכpare'-where both legs do not meet. Performers agree on what steps to be operated by each group. For instance, if right leg meets the one who took 'w 
The game can be performed either in groups or individually. It is played through jumping, clapping and throwing the legs forward. They sing and clap in addition to the throwing of legs. It continues till a winner is declared. Sometimes the last person is punished by few beatings.

Examples of songs sung:

a) Wəhyia, hyie wכpare

b) Bobə kəsi tire

c) Yeate yen ka, yeate yen ka

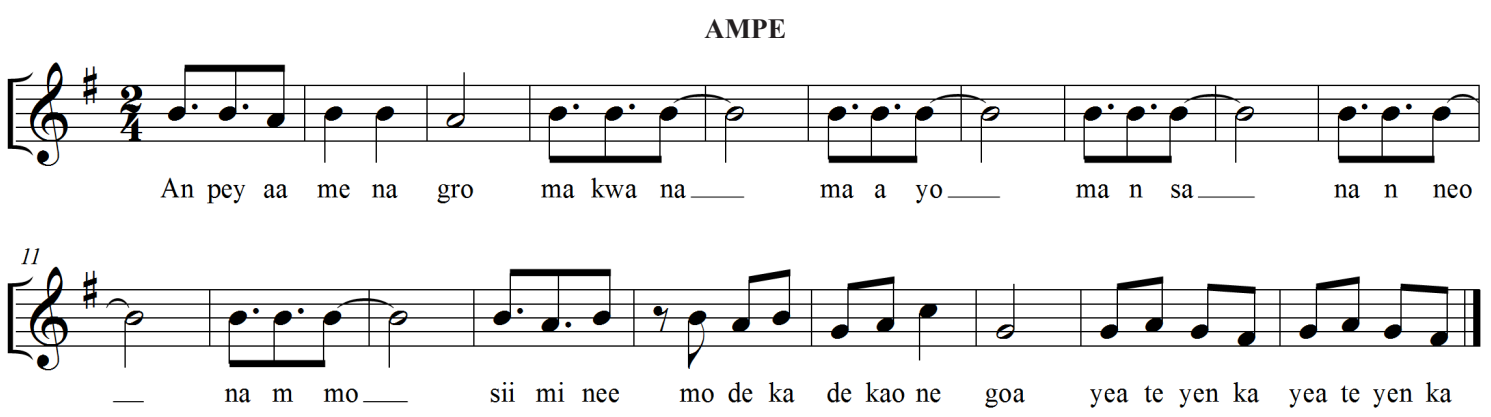

Source: Field Survey, 2019

\section{Educational implications of the ethno-musical games}

The study found ethno-musical games to be helpful in children's physical development, which enables them to gain control over the co-ordination and movement of all parts of their body. Through the musical games, the children were able to satisfy the intellectual and social aspirations by contacts with persons and objects as there was a strong co-ordination between their physical and cognitive domains. The cognitive abilities or skills of the child are improve upon and he is in a position to use his intellectual ability in solving problems through musical games. When children involve in games, they develop the problem-solving skills as found in "Mep\& Kwan Akə", where there seems to be no way, but the child manages to find a solution by outwitting his playmates. This study confirms Sinaga et al. ${ }^{[22]}$ and Zdravković et al. ${ }^{[16]}$ that musical games help children advance in language skills, increasing memory, and promoting emerging literacy.

When children involve themselves in games, they tend to socialize with each other and provide a very good environment for the formation and fostering of good social relations and friendship. The games foster understanding, acceptance of and conformity to constraints and rules. Children learn through games, to accept the views, actions and behaviour of other as well as confirm to laid down rules and regulations that are attached to every game. They learn to be empathic, recognizing and feeling for other people's emotions. For example, the games 'Hwehwe W'adamfo' and 'Yi wo d Jfo' help children to be in close contact with their friends and make new ones. As the games progress, children move from one end to the other to pick a friend or lover. They learn to play with one another in concert thus doing away with any form of antagonism. This finding buttresses that of Pogue ${ }^{[24]}$ and Macnamara et al. ${ }^{[19]}$ that musical games help children's social learning environments, and it is the social interaction that promotes bonding between individuals while supporting and extending learning.

In performing musical games children gain self-confidence. Leaders as well as other participants in all the games attain self-discipline. The children develop the habit of playing the role of personalities and animals in portraying the characters involved in the game, as is seen in "Sansankrom" where one becomes the "hawk" whilst the others simulate "chickens". The game "Tuwe, Tuwe" teaches children to be obedient, lead good moral lives and be chaste so that they are properly married and wedded as in the case of Maria. When children perform these games, they learn to persevere in life and develop the fighting spirit. Searching for "treasure' in "Piiloloo" helps develop such spirit in them.

The study further found that musical games to promote alertness in children. There is much concentration as they perform those games such as the "Stone-Passing" one. The individual has to be very alert in order to avoid any sluggish attitude, which would lead to heaping of stones in his area of operation. Musical games help children to learn cognitive concept. In "Mpeewa" where there are complex rhythmic patterns to be articulated using the hands, children are able to do a lot of calculations and fit in at the right time. In "Dua o Dua", children are able to think very fast and respond spontaneously to the cantor's call. The individual is able to determine whether the rat, goat, cow, or crab has a tail. Games assist children getting information about people, events and objects. The "Kyere Wo Ti" game helps children to name the various parts of the human body. "Touch your head, eye, ear, neck etc." gives the children the chance of touching those part 
mentioned. This corroborates the findings Ehrlin and Gustavsson ${ }^{[4]}$ that children who are immersed in music and language are more prepared to listen, more receptive and alert, and more active in their responses.

Music, and for that matter, musical game is another valuable way of developing a child's creative instincts. In musical games, various instinctive tendencies such as that of love, play, are made use of. The child's imaginative power is very much enhanced as he listens and guesses where his mates are, listening to where their voices come from and tying to locate and catch them in the "Mo WO hen o".

\section{Conclusion and policy implication}

The study has identified several ethno-musical games among children in the Akan enclave in Ashanti region. It was revealed that Play and Games play a vital role in the development and education of the child. In all the musical games found in this work, the children make maximum use of their bodies and muscles. The children's musical talent and aspirations are truly unearthed when he plays games, and whatever the situation, be it social, economic or political, all children must be given the opportunity to play musical games. It was found that movement itself serves to identify the best possible means of musical expression. Children are usually able to "discover" musical laws such as repetition, contrast, gradation, in functional types of music and dance-usually in the pieces expressing the mood of characters and situations. In the designed music and movement activities for pre-schoolers we used music perception, singing songs, games on the body parts, the elements of pantomime, or the types of walking, dancing and expressive speech. The leadership spirit and role is manifested as children play games. In the "Kyekyekule", "Bankye bankye" or "Pempenaa" musical games, children exhibit their leadership styles, which lead them to become good leaders later in life. They learn to endure suffering through the "Dua o Dua" game where a defaulter is punished after the offence. They learn also to accept defeat humbly when they lose.

The children develop their motor skills, which grow well during infancy, and is able to gain mastery over the movement and co-ordination of all parts of their body through the performance of musical games. The child is able to socialize and make friends and understand himself, and others, learning to accept others, learning to accept other people's views. The child learns to obey laid-down regulations and constructively rejoice in victory and accept defeat humbly. He learns to be obedient, develops the attitude to endure suffering. By engaging in musical games, the child is training himself to be alert and conscious as well as form the habit of concentrating on his present and future life.

As the children engage themselves in varied activities, their physical and motor skills are increased. It is therefore very important and necessary that children are exposed to a wide variety of such games to unearth those skills. Educational Policy to enforce music and dance subject at the early childhood levels is imperative for the cognitive development of children. Teachers should endeavour to apply the ethno-musical games in their classroom teaching as the students are familiar with them to enhance academic work. Regular application of musical games is critical to enhance the psychomotor and affective domains of children. 


\section{References}

[1] Chang, S. "Hear, feel, think": Musical narrativity in Final Fantasy XIV. Children. 2018; 20-25. Available from: https:// www.naeyc.org/files/yc/file/201109/Moving\%20Bodies_Russo_Marigliano_Online_0911.pdf.

[2] Koons N, Haungs M. Intrinsically musical game worlds: abstract music generation as a result of gameplay. InProceedings of the 14th International Conference on the Foundations of Digital Games. 2019. p.1-4.

[3] Braguinski, N. Musofun: Joseph Schillinger's Musical Game between American Music, the Soviet Avant-Garde, and Combinatorics. American Music. 2020; 38(1): 55-77.

[4] Ehrlin, A., Gustavsson, H. The Importance of Music in Preschool Education. Australian Journal of Teacher Education. 2015; 40(7). Available from: http://dx.doi.org/10.14221/ajte.2015v40n7.3.

[5] Cooper, S. Lighting up the brain with songs and stories. General Music Today. 2010; 23(2): 24-30. Available from: http://gmt.sagepub.com.

[6] Carson T. Mesh Garden: A creative-based musical game for participatory musical performance. InNIME; 2019. p.339-342.

[7] Georgii-Hemming, E. Music as knowledge in the educational context. In: E. Georgii-Hemming, P. Burnard, S-E. Holgersen. (eds.) Professional Knowledge in Music Teacher Education. 2013.

[8] Heyworth, J. N. Developing Social Skills Through Music: The Impact of General Classroom Music in an Australian Lower Socio-Economic Area Primary School. Childhood Education. 2013; 89(4): 234-242. Available from: https:// www.10.1080/00094056.2013.815553.

[9] Melters DP, Nye J, Zhao H, Dalal Y. Chromatin dynamics in vivo: a game of musical chairs. Genes. 2015; 6(3): 751776.

[10] Walton, PD. Using singing and movement to teach pre-reading skills and work reading. 2014.

[11] Hicks, C., Izumi-Tayloe, S., Meredith, C.D., Morris, V.G. Music and Movement for young children's healthy development. Dimensions of Early Childhood. 2012; 40(2): 33-39.

[12] Marigliano, M., Russo, MJ. Moving bodies, building minds: foster preschoolers' critical thinking and problem solving through movement. National Association for Young music programs for young children can foster their emotional, social, cognitive, and musical development. Music and Early Childhood. 2011; 30-34.

[13] Ani, S. Tillman, DA. Music activities as a meaningful context for teaching elementary students mathematics: a quasiexperiment time series design with random assigned control group. European Journal of Science and Mathematics Education. 2015; 3(1): 45-60.

[14] Garvis, S. Pendergast, D. Supporting novice teachers of the arts. International Journal of Education \& the Arts. 2014; 11(8). Available from: http://www.ijea.org/v11n8.

[15] Pasinski AC, Hannon EE, Snyder JS. How musical are music video game players? Psychonomic bulletin \& review. $2016 ; 23(5): 1553-1558$.

[16] Zdravković, V., Malinović-Jovanović, N., Dejković, M. Musical Games in Classroom Teaching. UDC; 2018.

[17]Fonteles JH, Fernandes MS, Queiroz DL, Rodrigues MA. Interactive Musical Game with a Gesture-Controlled Virtual Puppet. In 2017 19th Symposium on Virtual and Augmented Reality (SVR) IEEE. 2017. p.261-270.

[18] Garvis, S. Pendergast, D. An investigation of early childhood teacher self-efficacy beliefs in the teaching of arts education. International Journal of Education \& the Arts. 2011; 12(9): 1-15.

[19] Macnamara, BN., Hambrick, DZ., Oswald, FL. Deliberate Practice and Performance in Music, Games, Sports, Education, and Professions A Meta-Analysis. Psychological Science. 2014.

[20] Wiggins, DG. Pre-K music and the emergent reader: promoting literacy in a music enhanced environment. Early Childhood Education Journal. 2018; 1: 55-64. Available from: https://ink.springer.com/article/10.1007/s10643-0070167-6.

[21] Bintz, W. Singing across the curriculum. The Reading Teacher. 2010; 63(8): 683-386.

[22] Sinaga, SS., Rohidi, TR., Soesanto, Ganap, V. Musical Activity in The Music Learning Process Through Children Songs in Primary School Level. Harmonia: Journal of Arts Research And Education. 2018; 18(1): 45-51. Available from: http://dx.doi.org/10.15294/harmonia.v18i1.12508.

[23] Van Elferen I. Analysing game musical immersion: The ALI model. Ludomusicology: Approaches to Video Game Music. 2016; 32-52.

[24] Pogue, BJ. Using Music and Movement to Enhance Cognitive Development. Master's Theses \& Capstone Projects. 2018. Available from: https://www.tandfonline.com/doi/abs/10.1080/03004430802396530.

[25] Kružlicova, M. Pohybove a relaxačne cvičenia (Movement and relaxation exercises), Bratislava. Learning and behavior. Early Childhood Development and Care. 2013; 180(6): 799-808.

[26] Salmon, A. Using music to promote children's thinking and enhance their literacy. 2010.

[27] Strickland, S. Review of research: music and the brain in childhood development. Childhood Education. 2018; 78(2): 
100-103. To kindergarten children: an exploratory study. Language and Literacy. 2018; 16(3): 54-57. Available from: https://search.proquest.com/openview/9f4f612060fdd51a99d4691f49b26828/1?pq-origsite=gscholar\&cbl=28315.

[28] Geist, K., Geist, E., Kuznik, K. The patterns of music: young children learning mathematics through beat, rhythm and melody. Young Children: NAEYC. 2018; 67(1): 74-79. Available from: http://elf2.library.ca.gov/training/docs/ PatternsMusic Geist.pdf.

[29] Fonteles JH, Serpa YR, Barbosa RG, Rodrigues MA, Alves MS. Gesture-controlled interactive musical game to practice hand therapy exercises and learn rhythm and melodic structures. In 2018 IEEE 6th International Conference on Serious Games and Applications for Health (SeGAH). 2018. p.1-8.

[30] Mazzola G. Mathematical Music Theory and the Musical Math Game-Two Creative Ontological Switches. In International Conference on Mathematics and Computation in Music. Springer, Cham; 2017. p.201-212.

[31] De Oliveira PA, Lotto EP, Correa AG, Taboada LG, Costa LC, Lopes RD. Virtual stage: an immersive musical game for people with visual impairment. In 2015 14th Brazilian Symposium on Computer Games and Digital Entertainment (SBGames) IEEE. 2015. p.135-141. Development. Early Childhood Development and Care. 2015; 180(7): 937-945. Available from: https://doi.org/10.1080/03004430802550755.

[32] Riggins J, McLennon SM. Testing a Musical Game Activity for Community-Dwelling Older Adults. Home Health Care Management \& Practice. 2020; 32(1): 22-7.

[33] Verešova, J. Tanec a tanečne aktivity (Dance and dance activities). 1st ed. Bratislava; 2015.

[34] Bown O. Ferguson S. A Musical Game of Bowls Using the DIADs. InNIME; 2016. p.371-372.

[35] Taheri H, Rowe JB, Gardner D, Chan V, Gray K, Bower C, Reinkensmeyer DJ, Wolbrecht ET. Design and preliminary evaluation of the FINGER rehabilitation robot: controlling challenge and quantifying finger individuation during musical computer game play. Journal of neuroengineering and rehabilitation. 2014; 11(1): 10. 